\title{
Research on the Mechanism of Synergetic Improvement between Accounting Control and Corporate Governance
}

\author{
Longlong Wang \\ Shandong College of Economics and Business
}

Keywords: accounting control, corporate governance, synergistic improvement

\begin{abstract}
In order to maintain the healthy and sustainable development of capital market, the improvement and enhancement of the basic system such as accounting control and corporate governance, are indispensable. With the development of the times, the modern enterprise system is gradually established and perfected, and the closeness of the relationship between corporate governance and accounting control has attracted more and more attention, however, the system playing a leading role between the two cannot get accurate explanation. Based on the Contract Theory of enterprises, this paper expounds the concepts of corporate governance and accounting control, and makes an in-depth study on the synergistic improvement mechanism between the two.
\end{abstract}

\section{Introduction}

Accounting control work mainly means that the government supervises and controls the quality of accounting information and accounting behavior in accordance with laws and regulations as well as all kinds of administrative means. Accounting behavior mainly refers to the accounting of funds and the disclosure of financial information to enterprises, which also includes audit certificate and related work carried on by accountants. Corporate governance mainly refers to solving those problems arising in forming principal-agent relationship in the process of separation of management right and ownership. It can be seen from practice that the purpose of corporate governance is not only to better protect the rights and interests of shareholders, but also to realize the maximization of enterprise value through scientific means and perfect mechanisms, and to make the interests of each part of enterprise more balanced through effective coordination. In recent years, financial fraud has occurred in both domestic and foreign capital markets, which has brought a series of huge blows to market economy. At the same time, it has caused economic losses to investors, seriously restricted economic development, and led to chaos of market order. After research on many aspects, it is found that there are defects in accounting rules, whose main cause are weak accounting supervision as well as a lack of corporate governance ability. So, China has invested a great deal of energy in the research of synergetic improvement mechanism of accounting management and corporate governance, and has made some progress in related work. With the deepening of research, relevant professional scholars have realized the importance of accounting control and corporate governance and the theoretical study of these two contents has become a worldwide problem.

\section{Concepts of Accounting Control and Corporate Governance}

Accounting control work mainly refers to the intervention of relevant accounting work by the government or enterprise accounting team to ensure that accounting work can be carried out correctly, reasonably and orderly. This intervention should be carried out and implemented in accordance with relevant policies, rules or regulations. Specifically, the main body of accounting control work should be relevant government departments or accounting groups, and the object of control work is specific accounting work, whose main contents include accounting information disclosure, accounting treatment methods, accounting work system, audit report form, audit procedures and methods carried out by CPA, CPA, the office and accountants, etc.

Corporate governance can be explained from two aspects of micromanagement and macro governance. Micromanagement refers to the supervision and restriction mechanism of the owners of 
a company to the personnel who are responsible for operating management. That is to say, the owners of company need to reasonably arrange the power and responsibility division between themselves and operators by making use of the establishment of system in order to promote the coordination and balance of the interests of all parties and ensure the steady development of the company. From the perspective of macro governance, the related work of corporate governance not only needs to guarantee the stock to realize the balance of operators through system and company mechanism, but also reasonably arrange more stakeholders. Therefore, core contents of corporate governance should be the rational allocation of control rights, the scientific supervision of company operators, and the establishment of a perfect evaluation mechanism and incentive mechanism to provide internal motivation for the rapid development of enterprises.

Accounting information mainly refers to economic information that accountants obtain in work practice, which can reflect the value of accounting subjects and the state of accounting activities, occuping an important position in the information contents of financial market. From the perspective of economics, accounting information can also be regarded as a form of commodity. The characteristics of commodity are manifested in two aspects of monopoly and public nature. It is these two contradictory characteristics that lead to the imbalance of supply and demand of information goods in the market, which further results in the failure of accounting information market. In order to solve these problems, we need strong external supervision pressure to control accounting information market, guarantee the effective supply of accounting information, improve the balance of supply and demand, and further improve accounting information market. The main body of this role is relevant government departments and accounting professional groups. In addition, there are two important contents in the theory of accounting control. First is the Theory of Public Interest. From the perspective of Theory of Public Interest, accounting control should be based on ensuring the maximization of social welfare. Relevant government departments and accounting professional groups mainly represent public interests. In the process of control, the main goal should be to improve the balance of control costs and social benefits, thus improving the allocation of resources in the market and enhancing public interest. Second is Equity. In this theory, it is believed that the control of accounting information disclosure needs to guarantee the symmetry of the disclosure of accounting information, and the right to obtain the opportunity of accounting information should be equal between the objects of accounting information disclosure. In the past market behavior, there have been a series of unfair competition in the market caused by asymmetric accounting information. This unequal competitive relationship can cause serious social consequences. For example, it may lead to unreasonable transaction costs, profit lowering in trade, market downturn, and liquidity of securities. Therefore, it is of great significance to strengthen the regulation of accounting information disclosure, and the management concept should be guided by market fairness.

\section{Analysis of the Relationship between Accounting Control and Corporate Governance}

Effective accounting control has a certain impact on corporate governance. On one hand, accounting control can improve the efficiency of corporate governance, enhance the standardization of corporate governance by system and laws, and ensure the legitimacy of accounting information disclosure. On the other hand, reasonable accounting control work is also able to guarantee that all information users from various departments in the company can get a comprehensive and accurate information supply, so as to improve the accuracy of the company's decision-making and improve the efficiency of its management. In the process of corporate governance, if there are no corresponding rules and regulations, from the economic point of view, all systems or institutions will take their own interests as the premise and put their own interests in the starting point of all activities. Based on this purpose, it is likely to result in problems or even financial scandals to corporate governance, which will eventually affect the normal operation and development of the company. In the accounting information relation network, information supplyers, users of information and investors are not symmetrical, since investors need accurate cross level information to guide investment behavior, which is the function of accounting information disclosure. Therefore, 
only by involving accounting control work in corporate governance and using administration means in accordance with laws and regulations, can we better supervise and standardize the process of accounting information disclosure and ensure that all participants in the company have equal opportunities to obtain accounting information. Therefore, accounting control and corporate governance can better ensure the normal order of corporate affairs and improve the stability of capital market and securities market. However, it should also be noted that any involved force should follow the principle of moderation, in order to better ensure the balance of interests of company, so that company can be in a stable development.

The development of corporate governance also pose new challenges and problems for accounting regulation. At the same time, economic development put forward new requirements for accounting regulation as well. In order to adapt to the development of company, accounting control must make clear the way of improvement, improve work function, and provide guarantee for corporate governance by establishing a more scientific system. This requires accounting control work to be further improved so as to better serve corporate governance. Corporate governance is the prerequisite of accounting control activities. With the continuous progress of market economy, situation of corporate governance is more complicate, so management means need to be refined continuously and constantly improve the management ability of the company. As an effective means to restrain financial accounting work, accounting control can better guarante the company's normal operation. At the same time, the effectiveness of corporate governance is also the motive force of the continuous progress of accounting control, but with the continuous development and expansion of the company, accounting control should be changed to adapt to the development of the company and the operation of the market.

\section{Research on the Synergetic Improvement Measures of Accounting Control and Corporate Governance}

With the development of economy and constant adjustment and change of market, the traditional accounting management system has been unable to adapt to the development needs of company in the new period. The main manifestation is that the accounting supervision system is out of control to accounting management, which can not achieve the established goal of accounting control with weak basic work ability and weak supervision function. In order to better improve the accounting management system, it is necessary to combine the characteristics of the development of the times and take corresponding innovation measures so that accounting management system can play a better function.

Relevant legal liability of our country is still not perfect. It is mainly manifested in the lack of clear definition between securities legislation and civil liability. Only the provisions of criminal responsibility and civil litigation are relatively perfect. Therefore, illegal behavior in the disclosure of accounting information can only be restricted by the way of civil litigation. In the slecurities law, in view of seven kinds of accounting behaviors that appear in the listed companies, only principle provisions have been made and implementation measures are not clear enough, which lead to great difficulties in the final implementation. Therefore, in view of the above problems, it is necessary to improve and establish a perfect securities legislation. Especially, there should be clear legal liability provisions to punish those who have violated the principle of accounting information disclosure, or to protect the party who has suffered lost in the illegal disclosure of accounting information. Besides, it is also needed to establish a sound litigation mechanism which is propitious to track down responsibilities. The improvement of related mechanism of securities market can better protect the economic interests of charitable enterprises and SMEs as well as various types of company investors, and can effectively increase the expected costs of fraudulent parties, thus realizing the effective control of the behavior of all parties, improve the rate to find fraud, and improve corporate governance mechanism.

The establishment of legal environment relies mainly on the determination and effective implementation of legal liability. On the basis of definite laws and regulations, companies should also strengthen accounting control, establish reward and punishment standards, so that the offenders 
will pay a greater price. For example, it can be stipulated that, once accountants are involved in forgery and intentional destruction of important vouchers and constitute a crime, the criminal responsibility must be investigated according to law. If a crime is not constituted, different amounts of fines should be imposed to better regulate accounting behavior.

\section{Conclusion}

To sum up, accounting control and corporate governance directly affect the development of capital market. Both of them can develop together, innovate and improve related mechanisms, so as to better guarantee the development of companies, improve the stability of operation, reduce the impact of financial problems on work, and also promote the development of companies to be more in line with national laws and regulations, ensure the management to be more standardized and invincible in the future development.

\section{References}

[1] Qi Haodong. Corporate Governance Orientation of Accounting Control: Experience and Enlightenment [J]. Accounting Research, 2005, 07:13-18+96.

[2] Qi Haodong. Corporate Governance Orientation of Accounting Control: Empirical Evidence and Enlightenment [A]. China Accounting Society, Education Branch of China Accounting Society. Collection of Papers of 2005 Academic Annual Conference of Chinese Accounting Society (Last Volume) [C]. China Accounting Society, China Accounting Society Education Branch: 2005:9.

[3] Jiang Yanli. Analysis of Linkage Mechanism between Accounting Control and Corporate Governance [J]. SME Management and Technology (Late Issue), 2015, 11:93-94.

[4] Sun Kaibao. Research on the Effectiveness of Accounting Control from the Perspective of Corporate Governance [J]. Finance Monthly, 2012, 17:7-10.

[5] Zhang Xuenan, Wang Lihua. Analysis of the Relationship between Accounting Control Objectives and Corporate Governance [J]. Friend of Accounting (Middle Issue), 2007, 08:91-92.

[6] Hu Cheng. On Flexible Information Disclosure of Accounting Control and Accounting System [J]. Contemporary Economic Management, 2007 (06): 120-124.

[7] Chen Yan, Chen Yanli. Thoughts on Defects and Path Selection of Accounting Control of Government in China [J]. Financial Research, 2005 (12): 21-23. 